\title{
Relevansi Pemikiran Émile Durkheim Terhadap Usaha Revitalisasi Gereja Protestan Masa Kini
}

\author{
The Relevance of Émile Durkheim's Thoughts \\ for Protestant Churches Revitalization Today
}

\author{
Jessica Novia Layantara \\ Universitas Pelita Harapan Karawaci \\ jessica.layantara@uph.edu
}

\begin{abstract}
Abstrak: Makalah ini akan memberikan beberapa masukan dalam usaha revitalisasi gerejagereja Protestan masa kini, dengan menganalisis pemikiran kritis Émile Durkheim. Pengamatan dan kritik Durkheim mengenai Protestanisme pada zamannya akan dibandingkan dengan isu-isu yang dihadapi oleh gereja Protestan masa kini, seperti pola hidup individualistis jemaat, kurangnya solidaritas, kultus individual, kurangnya penghargaan terhadap sakralnya liturgi dan ibadah gereja termasuk perjamuan kudus, dan tidak adanya aturan gereja yang jelas. Selanjutnya, makalah ini juga menawarkan sebuah sintesis sistematikkonstruktif dari analisis tersebut, dalam rangka usaha revitalisasi gereja, yaitu rekonfirmasi simbol-simbol, reklarifikasi konsep sakral-nonsakral, dan reformasi yang melibatkan klanklan baru dalam gereja.
\end{abstract}

Kata-Kata Kunci: Émile Durkheim, Protestanisme, Revitalisasi Gereja, Totem

Abstract: This paper will provide some efforts to revitalize Protestant churches today, by analyzing the critical thinking of Émile Durkheim. Durkheim's observations and critiques of Protestantism in his day will be compared to the issues faced by the Protestant church today: the individualistic lifestyle of the congregation, lack of solidarity, individual cults, lack of respect for the sacred liturgy and church worship including holy communion, and no clear church rules. Furthermore, this paper also offers a systematic-constructive synthesis to revitalize the church, including: reconfirmation of symbols, reclarification of the sacred and nonsacred, and also reformation involving new clans in the church.

Keywords: Émile Durkheim, Protestantism, Church Revitalization, Totem 


\section{PENDAHULUAN}

Émile Durkheim adalah seorang sosiolog yang banyak berbicara mengenai dimensi sosial dari agama. Karya besarnya, The Elementary Forms of Religious Life (1912), merupakan buku sosiologi yang paling penting membahas mengenai agama. ${ }^{1}$ Di zaman pascamodern ini, para sosiolog modern menemukan bahwa pemikiran Durkheim mengenai agama layak diangkat kembali, khususnya di tengah praktik agama modern yang poststrukturalis dan individualis. ${ }^{2}$

Selain membahas agama secara umum, secara khusus Durkheim membicarakan Protestanisme di dalam magnum opus-nya tersebut, yang juga dapat ditemukan dalam karyakaryanya yang lain, seperti Suicide (1897) dan The Division of Labor in Society (1893). Meskipun bersikap apresiatif, Durkheim juga mengkritik Protestan sebagai agama yang individualistis, terlalu bebas, dan tidak memiliki batas antara yang sakral dan nonsakral. Meskipun Durkheim secara terangterangan mengkritik agama Protestan, kritik Durk-heim terhadap agama Protestan ini harus dipahami dalam konteks praktik keagamaan Protestan pada abad ke-19 di Perancis. Oleh sebab itu dapat dikatakan bahwa kritik Durkheim ini berpusat kepada praktik keagamaan Protestan pada zaman tersebut, daripada ajaran Protestan secara esensial. Demikian juga latar belakang Durkheim sebagai seorang sosiolog, dan bukan teolog, membuatnya lebih fokus pada fenomena praktik gereja daripada mendalami doktrin. Meskipun sudah beberapa abad berlalu, kritik Durkheim terhadap Protestan masih relevan sampai saat ini, terutama dalam praktik gereja-gereja Protestan

${ }^{1}$ W.S.F Pickering, Durkheim's Sociology of Religion: Themes and Theories (Cambridge: James Clark \& Co, 2009), xix.

${ }^{2}$ Thomas Idinopulos, "Preface," dalam Reappraising Durkheim for the Study and Teaching of Religion Today, ed. Thomas A. Idinopulos dan Brian C. Wilson (Leiden: Brill, 2002), 10. di masa kini juga menunjukkan ciri-ciri yang mirip seperti yang Durkheim katakan, sehingga kritik Durkheim dapat diapresiasi dan dimanfaatkan demi revitalisasi gereja di masa kini.

Konteks penelitian Durkheim tentang agama juga sangat cocok dengan konteks Indonesia. Durkheim meneliti masyarakat primitif yang bersifat komunitarian, yang sedikit banyak mencirikan masyarakat Indonesia. Fitzerald Kennedy Sitorus berargumen bahwa pemikiran Durkheim cocok digunakan untuk meneliti masyarakat Indonesia "Durkheim's observation of social determinism in moral affairs finds a parallel in Indonesian society today and in the past." ${ }^{3}$ Masyarakat Indonesia bukan hanya mempraktikkan kesadaran kolektif dalam bermasyarakat, tetapi juga dalam ranah beragama. Hal ini menarik, mengingat bahwa di Indonesia juga banyak gereja Protestan, yang dikritik Durkheim sebagai komunitas yang individualis.

Oleh karena alasan-alasan di atas, makalah ini akan menganalisis secara khusus pemikiran kritis Émile Durkheim mengenai Protestanisme, yang diharapkan pada akhirnya akan memberikan beberapa usul dalam usaha revitalisasi gereja-gereja Protestan masa kini di Indonesia. Bagian pertama dari makalah ini akan membahas secara singkat pemikiran Durkheim tentang agama dan kritik Durkheim di masa lalu mengenai agama Protestan. Bagian kedua akan berisi komparasi pandangan dan kritik Durkheim dengan isu-isu yang dihadapi oleh gereja Protestan masa kini. Selanjutnya di bagian ketiga, makalah ini juga menawarkan sebuah sintesis sistematik-konstruktif dalam rangka usaha revitalisasi gereja berkaitan dengan isu-isu yang dibahas di atas. Usaha-usaha tersebut disadur dari pemikiran Durkheim,

${ }^{3}$ Fitzerald Kennedy Sitorus, "Theonomous, Autonomous, and Heteronomous Conscience: Conscience in Luther and Kant, and Indonesian Moral Perception," dalam Sola Scriptura in Asia, ed. Yongbom Lee and Andrew R. Talbert (Oregon: Wipf and Stock, 2018), 103. 
dan menghasilkan tiga ajuan solusi bagi revitalisasi gereja masa kini, antara lain: rekonfirmasi simbol-simbol, reklarifikasi konsep sakral-nonsakral, dan reformasi yang melibatkan klan-klan baru dalam gereja.

\section{PEMIKIRAN DURKHEIM TENTANG AGAMA DAN KRITIKNYA TERHADAP PROTESTANISME}

Pemikiran Durkheim mengenai agama di bagian ini akan diuraikan dalam empat bagian singkat, yaitu pemikiran Durkheim tentang komunitas sebagai agama, pemikiran Durkheim tentang totemisme sebagai praktik beragama, konsep sakral dan nonsakral dalam agama, serta konsep kepercayaan (belief) dan ritual dalam agama. Setelah itu, akan dibahas kritik Durkheim terhadap Protestanisme.

\section{Komunitas sebagai Agama}

Durkheim memandang agama sebagai fenomena sosial, dan bukan cerminan penyembahan kepada yang supranatural ataupun misterius. Karakteristik paling esensial yang membentuk agama adalah komunitas. Dalam karyanya The Elementary Forms of Religious Life, Durkheim menempatkan agama sebagai "the first and foremost a system of ideas by means of which individuals imagine the society of which they are members and the obscure yet intimate relations they have with it."4

Komunitas agama adalah komunitas terintim karena terdiri dari orang-orang yang memiliki kepercayaan yang sama, dan kemudian membentuk nilai-nilai dan standar moral yang sama. Durkheim meyakini bahwa tidak ada satupun agama yang lepas dari komunitas atau konteks sosial. Tidak ada agama yang individualis. Setiap agama memiliki "gereja," yang merupakan istilah

${ }^{4}$ Emile Durkheim, The Elementary Forms of Religious Life, ed. Karen E. Fields (New York: The Free Press, 1995), 227.
Durkheim untuk komunitas agama. Komunitas adalah aspek utama dan terutama dalam agama, bahkan Durkheim menyamakan agama dengan penyembahan terhadap komunitas itu sendiri. ${ }^{5}$ Hal tersebut akan dibahas di bagian yang selanjutnya.

\section{Totemisme}

Totemisme adalah bentuk pengkultusan simbol-simbol tertentu (totem) yang dilakukan oleh suku-suku primitif. Totem-totem yang disembah oleh suku primitif terdiri dari berbagai bentuk dan berbeda di setiap klan (bagian terkecil dari sebuah suku). Totemtotem ini bisa berupa benda-benda yang dianggap suci, seperti patung, batu, pohon, awan, hujan, matahari, dan lain-lain. Totem juga bisa berbentuk binatang atau bagian dari binatang, contohnya penyembahan terhadap binatang tertentu secara utuh, atau hanya bagian tubuh binatang seperti lemak atau ekor.

Menurut Durkheim, totemisme primitif bukanlah cerminan dari Yang Mahakuasa, melainkan cerminan atau simbol dari komunitas itu sendiri. Namun lama-kelamaan, karena totem itu terus menerus digunakan turun temurun maka totem itu dianggap sakral dan melambangkan Yang Mahakuasa. Hal ini menyebabkan bertambahnya fungsi totem, bukan lagi hanya untuk merepresentasikan klan tersebut, namun juga sebagai lambang religius dari agama. Sebagai lambang dari yang Mahakuasa, totem juga berfungsi menjelaskan alam semesta dan isinya. Fungsi totem untuk menjelaskan segala sesuatu ini disebut sebagai pantotemism. ${ }^{6}$

\section{Konsep Sakral (Sacred) dan Nonsakral (Profane)}

Menurut Durkheim, manusia secara sadar ataupun tidak sadar, selalu membagi segala

${ }^{5}$ Ibid., 41.

${ }^{6}$ Ibid., 118. 
sesuatu yang ia ketahui dan segala realitas yang ia alami ke dalam dua kategori: sakral (sacred) dan nonsakral (profane). Dibandingkan yang nonsakral, Durkheim lebih banyak membahas kategori sakral, yang dianggap Durkheim sebagai hal yang membentuk identitas manusia.

Kategori sakral berhubungan dengan kepercayaan, mitos, dogma, dan legenda. ${ }^{7}$ Dalam perwujudannya, hal-hal yang sakral tercermin dalam totem-totem yang dibuat. ${ }^{8}$ Halhal sakral tersebut sendiri merupakan identitas dan kesepakatan dari komunitas tersebut. Dalam konteks komunitas, hal-hal sakral yang disepakati bersama pada akhirnya membentuk agama. Sebaliknya, istilah nonsakral atau profan merujuk kepada hal yang sehari-hari. Hal-hal ini tidak digolongkan sebagai hal yang negatif oleh Durkheim, melainkan nonsakral. Hal-hal yang nonsakral tidak berada di bawah totem.

\section{Konsep Kepercayaan (Belief) dan Ritual}

Durkheim membagi dua unsur dalam sebuah agama, yaitu kepercayaan (belief) dan ritual. Kepercayaan merupakan unsur yang lebih rasional dalam sebuah agama. Kepercayaan mencakup doktrin, ajaran, pengakuan iman, tuntunan moral, dan mitos. Sedangkan ritual lebih bersifat irasional, di mana ritual adalah "sebuah kekuatan eksternal yang membuat manusia melakukan sesuatu dalam cara-cara tertentu." diwujudkan lewat praktik-praktik yang dilakukan dalam agama tersebut, baik ibadah, tari-tarian dan nyanyi-nyanyian, persembahan korban, dan lain-lain, yang dilakukan bersama-sama dalam komunitas.

Durkheim secara pribadi menganggap ritual sebagai unsur yang lebih penting dalam agama dibandingkan unsur kepercayaan. Ritual, yang selalu dilakukan bersama-sama, mem-

${ }^{7}$ Ibid., 35.

${ }^{8}$ Ibid., 118.

${ }^{9}$ Ibid., 364. bangun sebuah emosi positif yang sifatnya kolektif (collective effervescence). Ritual juga menciptakan solidaritas dalam sebuah kelompok tertentu. ${ }^{10}$ Ketika solidaritas terbangun sebagai hasil dari ritual, maka masingmasing individu dalam komunitas tersebut memiliki tendensi untuk melindungi dan menghormati komunitas tersebut.

\section{Kritik Émile Durkheim terhadap Kekristenan dan Protestanisme}

Menurut Pickering, Durkheim memiliki pandangan yang positif tentang Kekristenan secara umum. ${ }^{11}$ Pengajaran mengenai penebusan Kristus atas manusia menghimbau orang Kristen untuk mengasihi sesama manusia. Durkheim juga memuji Kekristenan dalam mengajarkan "simple way of life," yang mana cara hidup seperti demikian menarik banyak kalangan, khususnya orang-orang miskin. Kekristenan juga sangat hebat dalam bidang pendidikan, alasannya adalah karena Kekristenan sangat menekankan pemikiran rasional dalam pengajaran-pengajarannya. ${ }^{12}$

Namun demikian, Durkheim juga mengkritik agama Kristen, khususnya Protestan. Sebelum masuk ke dalam kritik Durkheim, perlu ditekankan bahwa kritik Durkheim ini sebenarnya lebih kepada fenomena yang ia temukan pada zamannya, yaitu abad ke-19 di Perancis. Durkheim adalah seorang sosiolog, dan ia tidak mendalami teologi, sehingga kritik Durkheim lebih kepada praktik keagamaan Protestan pada zamannya. Pada zaman itu, Protestanisme sangat berkembang di Perancis, khususnya di bawah seorang teolog bernama Auguste Sabatier. Sabatier adalah seorang Protestan liberal dan rasionalis, yang berusaha menggali relasi antara agama dan sains. Menurut Donald A. Nielsen, Durkheim dan peneliti lainnya mengenai Durkheim tidak pernah menyebut nama Sabatier dalam karya-karyanya, namun

\footnotetext{
${ }^{10}$ Ibid., 365.

${ }^{11}$ Pickering, Durkheim's Sociology of Religion, 422.

${ }^{12}$ Ibid., 426.
} 
bagi Pickering dan Nielsen, sangat jelas bahwa kritik Durkheim pada Protestanisme tidak lepas dari apa yang dilakukan Sabatier. ${ }^{13}$

Durkheim memiliki beberapa kritik terhadap agama Protestan. Menurut Durkheim, Protestan adalah agama yang mempromosikan individualisme. Pendekatan yang individualistik dari Protestan membuat penganut agama ini kurang memiliki solidaritas dan ikatan yang kuat terhadap komunitas Protestan sendiri.

Agama Protestan juga merupakan agama yang lebih banyak memberikan kebebasan pada umatnya dibandingkan agama Katolik. ${ }^{14}$ Kebebasan yang diberikan agama Protestan membawa pengaruh yang buruk, salah satunya terhadap perilaku bunuh diri. Di dalam buku Suicide, Durkheim meneliti angka bunuh diri, yang salah satunya ia teliti berdasarkan agama yang dianut. Hasil penelitian Durkheim adalah angka bunuh diri tertinggi diraih oleh orang-orang yang beragama Protestan. ${ }^{15}$ Hal ini juga berhubungan dengan kurangnya aturan-aturan yang jelas dalam agama Protestan, sehingga membuat hidup jemaat terlalu bebas.

Protestan juga lebih menekankan aspek kepercayaan (belief) daripada ritual. ${ }^{16} \mathrm{Di}$ dalam aspek kepercayaan (belief), orang Protestan bebas menafsirkan Alkitab tanpa ada pakem tertentu yang harus diikuti, "The Protestant is far more the author of his faith. The Bible is put in his hands and no interpretation is imposed upon him. The very structure of the reformed cult stresses this state of religious

${ }^{13}$ Donald A. Nielsen, "Auguste Sabatier and the Durkheiminians on The Scientific Study of Religion," Sociological Analysis 47 (1987): 284.

${ }^{14}$ Emile Durkheim, Suicide: A Study in Sociology, terj. John A. Spaulding and George Simpson (London: Routledge Classics, 2002), 113.

${ }^{15}$ Ibid.

${ }^{16}$ Emile Durkheim, The Division of Labor in Society, ed. Lewis A. Coser, terj. W.D. Halls (London: Macmillan, 1984), 114. individualism."17 Dalam aspek ritual, Protestan memberi banyak kebebasan pada masing-masing individu untuk memiliki hubungan dengan Allah dalam cara mereka masing-masing. Ritual-ritual yang dilakukan bersama-sama memang masih ada, tetapi tidak lebih penting dari doa yang dinaikkan secara pribadi. Sosok Tuhan yang disembah dalam agama Protestan adalah Tuhan yang tidak ditemui lewat kegiatan ritual ataupun material, melainkan lewat hubungan rohani atau spiritual. ${ }^{18}$ Tentu saja hal ini membuat jemaat Protestan lebih individualis.

Selanjutnya, Durkheim mengkritik Protestan sebagai agama yang tidak memiliki simpati terhadap konsep sakral itu sendiri. ${ }^{19}$ Agama Protestan meleburkan jarak antara yang sakral dan nonsakral, dan hasilnya adalah sekularisasi, modernisasi dan kultus individual.

\section{RELEVANSI PEMIKIRAN DURKHEIM TERHADAP REVITALISASI GEREJA MASA KINI: SOLUSI-SOLUSI AJUAN}

Bagian ini akan membandingkan kritikkritik Durkheim terhadap Protestanisme di atas dengan isu-isu yang dihadapi gereja masa kini, serta memberikan solusi-solusi ajuan. Isu-isu masa kini dibagi menjadi tiga bagian: identitas gereja, kesakralan gereja, dan pertumbuhan gereja. Adapun solusi ajuan yang diberikan adalah rekonfirmasi simbol-simbol untuk menjawab isu identitas gereja, reklarifikasi konsep sakral dan nonsakral untuk menjawab isu kesakralan gereja, dan reformasi yang melibatkan klan baru dalam gereja untuk menjawab isu pertumbuhan gereja.

\footnotetext{
${ }^{17}$ Durkheim, Suicide: A Study in Sociology, 112. Hal ini juga harus dilihat tidak lepas dari konteks Protestan abad ke-19 di Perancis.

${ }^{18}$ Pickering, Durkheim's Sociology of Religion: Themes and Theories, 423.

${ }^{19}$ Ibid., 159-160.
} 


\section{Isu Identitas Gereja: Rekonfirmasi Simbol-simbol}

Kritik yang diajukan Durkheim terhadap Protestanisme adalah bahwa agama ini mengembangkan individualisme. Penulis tidak sepenuhnya setuju dengan kritik Durkheim berkaitan dengan hal ini, khususnya bahwa ajaran agama Protestanlah yang menyebabkan praktik individualisme dalam gereja. Jika kembali kepada Alkitab, jelas bahwa praktik individualisme yang berkembang dalam gereja bertentangan dengan identitas gereja sendiri, yang adalah merupakan komunitas orang percaya dan satu tubuh Kristus. ${ }^{20}$ Alkitab jelas mengajarkan identitas esensial gereja sebagai persekutuan dan tubuh Kristus. Namun demikian tidak disangkali bahwa dalam praktik gereja masa kini, sikap individualisme terlihat dengan jelas.

Pertama, fenomena isu ini terlihat dalam banyaknya perpecahan yang terjadi dalam gereja. Penulis sama sekali tidak menolak pembentukan denominasi baru. Namun harus disadari bahwa dari pembentukan denominasi baru ini, ada unsur persaingan antar denominasi yang berujung pada perpecahan. Perpecahan ini dapat muncul karena berbagai faktor: persaingan jumlah jemaat, masalah keuangan, kekecewaan pada denominasi sebelumnya, perbedaan doktrin/ajaran, dan lain-lain. Sony Dandel berkomentar,

Gejala di atas (pertambahan denominasi) secara alamiah memunculkan tandingan, yang biasanya hadir dari komunitas agama tradisonal yang enggan kehilangan domba atau kehilangan jati diri, atau dari komunitas baru yang kecewa dengan komunitas lama yang kurang kokoh berjuang memerangi perkembangan pertama ... Gejala kedua biasanya bermuara pada suatu bentuk keagamaan yang fundamentalistis dan

${ }^{20}$ Louis Berkhof, Teologi Sistematika 5: Doktrin Gereja (Surabaya: Momentum, 2003), 23. berpusat pada kelurusan ajaran. Dengan demikian, tidak mengherankan jika faktor ajaran jadi amat dominan. ${ }^{21}$

Hal ini bertentangan dengan identitas gereja yang merupakan komunitas orang percaya yang dipersatukan oleh Kristus, namun ini adalah kenyataan yang terjadi dalam praktik gereja.

Kedua, isu ini terlihat dalam kurangnya solidaritas dalam gereja. Dalam bukunya, The Division of Labor in Society (1893), Durkheim membedakan antara solidaritas organik dengan solidaritas mekanik. Solidaritas organik adalah solidaritas yang terbangun karena rasa saling ketergantungan untuk memenuhi tujuan tertentu, dan dalam memenuhi tujuan ini ada pembagian kelas/ status. ${ }^{22}$ Sedangkan solidaritas mekanik adalah solidaritas yang terbangun karena kesamaan-kesamaan: kesamaan ekonomi, sentimen moral dan nilai-nilai yang disebut sebagai kesadaran kolektif. Menurut Durkheim, solidaritas mekanik hanya didapatkan melalui agama.

Pada awalnya Kekristenan bertumpu pada solidaritas mekanik, hal ini tampak dalam cara hidup gereja mula-mula. Namun menurut Durkheim, akibat populasi yang bertambah, mulai adanya pembagian kelas dalam masyarakat, dan perubahan dalam dunia kerja dan industri membuat Protestanisme beralih kepada solidaritas organik. Demi mengakomodasi kepercayaan dan nilai moralnya dalam masyarakat modern, Protestanisme menyesuaikan teologinya dengan pembagian kelas-kelas kerja. ${ }^{23}$ Akibatnya adalah

\footnotetext{
${ }^{21}$ Sony Dandel, "Pandangan Pemimpin Gereja tentang Pengaturan Organisasi Gereja di Kota Surabaya, Jawa Timur," dalam Pemimpin Gereja Moratorium Organisasi Gereja dan HAM, ed. Nuhrison M. Nuh (Jakarta: Puslitbang Kehidupan Keagamaan Badan Litbang dan Diklat Kementerian Agama RI, 2015), 249-250.

${ }^{22}$ Durkheim, The Division of Labor in Society, 316.

${ }^{23}$ Joseph Scimecca, Christianity and Sociological Theory: Reclaiming the Promise (London: Routledge, 2018).
} 
prinsip utilitarianisme, kapitalisme, dan pementingan terhadap produksi dan hasil. ${ }^{24}$ Hal ini tampak juga dalam praktik bergereja, solidaritas organik tampak di dalam pelayanan gerejawi, di mana masing-masing jemaat diberi kesempatan untuk berkontribusi dalam kemajuan gereja sesuai dengan keahlian mereka masing-masing. Hal yang baik ini juga dapat menjadi ekses: Jemaat yang berkontribusi lebih banyak bagi gereja lebih dihargai, ada bentuk-bentuk pelayanan yang tampaknya lebih diunggulkan daripada yang lain. Solidaritas organik membagi, sadar ataupun tidak sadar, kelas-kelas dalam jemaat, sebagaimana dalam masyarakat modern, pekerja dibagi juga dalam kelas-kelas.

Solusi yang diajukan untuk masalah krisis identitas gereja ini adalah dengan cara rekonfirmasi simbol-simbol. Simbol, menurut Durkheim, membuat benda-benda biasa yang ada di sekitar kita memiliki nilai kolektif yang penting. ${ }^{25}$ Durkheim memberi contoh sebuah bendera, yang terbuat dari kain biasa yang dijahit, namun demi sebuah bendera banyak orang yang bersedia mengorbankan diri. Di samping itu, bendera juga menjadi lambang identitas suatu bangsa. Demikian pula, simbol di dalam sebuah agama, menurut Durkheim, membuat orang-orang yang memegang agama tersebut merasa sebagai satu komunitas, dan melalui simbolsimbol pulalah solidaritas mekanik terbangun. Selain harus bermakna religius, simbol yang digunakan harus merupakan simbolsimbol yang diterima oleh masing-masing orang dalam komunitas tersebut dan juga direkonfirmasi terus-menerus untuk membuatnya diingat dan bermakna bagi komunitas.

\footnotetext{
${ }^{24}$ Luiz Gustavo dan Cunha de Souza, "Division of Labour in Durkheim, Marx, and Honneth: Contributions to a Political Economy of Recognition," Civitas: Journal of Social Sciences 18, no. 3 (2018): 658, https:// doi.org/10.15448/1984-7289.2018.3.31068.

${ }^{25}$ Jacques Janssen dan Theo Verheggen, "The Double Center of Gravity in Durkheim's Symbol Theory: Bringing the Symbolism of the Body Back In," Sociological Theory 15, no. 3 (1997): 294, https://doi.org/10.1111/ 0735-2751.00036.
}

Masyarakat kuno Australia yang diteliti Durkheim (suku Arunta, Loritja, Kaitish, Unmatjera dan Ilpirra) memiliki simbol yang bermakna, baik secara religius maupun kolektif. Simbol ini disebut Churinga atau Tjurunga, yaitu kayu atau batu yang diasah dengan berbagai bentuk (biasanya oval atau lonjong), dan di atasnya diukir desain yang merepresentasikan totem dari komunitas tersebut. Churunga adalah simbol yang sangat sakral, tidak boleh sembarangan ditunjukkan pada orang asing dan juga disimpan di tempat yang khusus. Churunga memiliki makna religius-teologis, yaitu sebagai representasi totem, dan juga dipercaya dapat menghasilkan mujizat, seperti menyembuhkan luka dan penyakit. Churunga juga dipakai dalam upacara-upacara religius sebagai instrumen dalam ritual mereka. Namun demikian, Churunga juga memiliki makna kolektif, yaitu merupakan representasi dari komunitas itu sendiri. Durkheim mengatakan, "Losing them is disaster, the greatest misfortune that can befall the group ... It is a collective treasury, the Holy Ark of the clan." 26

Di dalam komunitas Protestan, terdapat juga simbol-simbol semacam ini, yang diakui oleh seluruh jemaat sebagai simbol religius sekaligus simbol komunitas. Simbol-simbol yang umum digunakan dalam Protestanisme adalah simbol salib dan juga roti dan anggur. Simbol salib merupakan simbol komunitas Kristen. Walaupun salib dianggap sebagai hukuman yang buruk, namun bagi komunitas Kristen, salib melambangkan penebusan dosa bagi umat manusia. Lambang salib juga digunakan dalam komunitas Kristen mulamula sebagai identitas mereka, membedakan komunitas Kristen dengan komunitas pagan. Di dalam gereja Protestan, bentuk salib dapat ditemukan sebagai aksesoris jemaat atau hiasan dalam gedung gereja, namun tidak lagi berbentuk ritual sebagaimana yang masih dilakukan umat Katolik: membuat tanda salib setiap kali mengawali dan mengakhiri doa.

${ }^{26}$ Durkheim, The Elementary Forms of Religious Life, 120-121. 
Salib dalam gereja Protestan pada umumnya lebih sering menjadi topik khotbah dan pengajaran doktrin dari pemimpin gereja. Dalam Protestanisme, simbol salib lebih mendekati bentuk dari doktrin (belief) daripada bentuk ritualnya. Padahal, sebagai sebuah simbol, sangat penting ditekankan aspek ritual yang melibatkan emosi dan pengalaman ekstatik, lebih dari sekedar pengalaman intelektual. ${ }^{27}$ Ritual akan membentuk emosi kolektif (collective effervescent), yang menghasilkan solidaritas mekanik. Menurut Riley, penggunaan salib dalam ritual, selain menghasilkan emosi kolektif, akan menghasilkan mimetic act, "The member of the totem clan imitates the totem because he really believes the same substance inhabits him, and he desires to imitate the totem principle just as, for example, the Christian wants to imitate Christ." ${ }^{28}$ Oleh sebab itu perlu adanya rekonfirmasi simbol salib dalam komunitas Protestan untuk menyadarkan kembali gereja akan identitasnya, khususnya rekonfirmasi dalam bentuk ritual yang melibatkan emosi daripada doktrinal. Contohnya, menggunakan video, musik, lagu salib dalam sebuah ibadah dan jemaat diajak merenungkan pentingnya simbol tersebut bagi komunitas Kristen, memasang sebuah lukisan salib di tengah mimbar dan mengajak jemaat merenungkan simbol tersebut, dan lain-lain.

Simbol penting lain yang menyangkut identitas gereja terdapat dalam ritual Perjamuan Kudus, di mana roti dan anggur melambangkan tubuh dan darah Kristus. Di dalam Perjamuan Kudus, bukan hanya peringatan akan Kristus yang dihayati bersama-sama, tetapi juga kesadaran gereja akan identitasnya, yang adalah komunitas yang dipilih oleh Kristus layaknya yang dilakukan gereja mulamula (Kis. 2).

\footnotetext{
${ }^{27}$ Janssen dan Verheggen, "The Double Center of Gravity in Durkheim's Symbol Theory: Bringing the Symbolism of the Body Back In,” 295.

${ }^{28}$ Alexander Riley, The Social Thought of Emile Durkheim (California: SAGE, 2015), 195.
}

Menurut Pickering, Durkheim sendiri sangat mengapresiasi ritual Perjamuan Kudus dan simbol-simbolnya dalam Protestanisme. Bahkan menurut Pickering, Durkheim terinspirasi dari ritual ini saat mengusung pemikirannya mengenai emosi positif secara kolektif yang dihasilkan dari ritual (collective effervescent). Pada akhirnya emosi kolektif inilah yang menciptakan solidaritas mekanik. Pickering mengatakan,

The first is the Christian eucharist, which is briefly referred to by Durkheim. The Last Supper celebrated by Christ with his disciples was, according to the New Testament, an event of extreme importance, of high emotional content, giving rise to new religious ideas-a great religious leader saying over bread and wine 'This is my body', 'This is my blood'. Here is a clear example of the creative type of effervescent assembly and it has always had a central place in Christian theology ... The combination of creative effervescent assembly and subsequent ritual re-enactment fits admirably Durkheim's concept, and one wonders if in fact he did not derive his ideas from this source. ${ }^{29}$

Sayangnya, di zaman modern ini Perjamuan Kudus dilakukan tanpa lagi menekankan aspek kebersamaan dan kesatuan dari komunitas Kristen. Robert N. Bellah berpendapat bahwa sejak Reformasi, ritual (termasuk Perjamuan Kudus) menempati posisi yang kurang penting dalam teologi Protestan. ${ }^{30}$ Semboyan Sola Scriptura membuat ritualritual Kristen awal, termasuk Perjamuan Kudus kehilangan makna ritualnya. Perjamuan Kudus hanya dipandang sebagai kegiatan "mengingat kembali pengorbanan Kristus," tanpa menekankan aspek kebersamaan

\footnotetext{
${ }^{29}$ Pickering, Durkheim's Sociology of Religion: Themes and Theories, 393.

${ }^{30}$ Robert N Bellah, "Durkheim and Ritual," in The Cambridge Companion to Durkheim, ed. Jeffrey C. Alexander and Philip Smith (Cambridge: Cambridge University Press, 2005), 205.
} 
komunitas sebagaimana gereja pertama. Kritik Bellah ini tampaknya tidak berlaku umum untuk semua ajaran Protestan. Ajaran Luther dan Calvin tidak memaknai Perjamuan Kudus hanya sebagai kegiatan mengingat kembali pengorbanan Kristus. Luther memegang doktrin konsubstansiasi, di mana Kristus hadir melalui roti dan anggur Perjamuan Kudus (Luther tidak mempercayai roti dan anggur mengalami perubahan menjadi tubuh dan darah Kristus layaknya pandangan Katolik). Calvin menekankan kehadiran Kristus di tengah jemaat melalui Roh Kudus saat ritual Perjamuan Kudus berlangsung. Jadi, pandangan Bellah tersebut kurang tepat untuk ditujukan pada Protestan secara umum, kecuali pandangan Zwingli. Namun demikian, simbol roti dan anggur memang mengalami penurunan makna. Menurut Gordon E. Pruett, khususnya pada pandangan Calvin (Reformed), simbol roti dan anggur tidak lagi menjadi fokus utama dari ritual, melainkan berpusat pada iman, "The symbols of faith become conduits rather than repositories; but they are symbols, and they do depend upon the transcendent for their power, even as they require faith for their actualization." "31 Iman di sini dimengerti sebagai sesuatu yang bersifat spiritual dan juga personal, meskipun ritual dilakukan secara bersama-sama dengan jemaat Kristen lainnya.

Demikian juga ada gereja-gereja yang menyalahgunakan ritual Perjamuan Kudus untuk hal-hal lainnya, seperti penyembuhan dan berkat materi saja. Hal ini menjadikan Perjamuan Kudus kehilangan makna dari simbol-simbolnya. Simbol-simbol ini bisa jadi sama dan dilakukan dalam ritual yang sama, tetapi tidak seragam diterima maknanya oleh komunitas Protestan. Oleh sebab itu, rekonfirmasi simbol-simbol adalah hal yang sangat penting dalam komunitas Protestan. Rekonfirmasi yang dimaksud di sini bukan sekedar

\footnotetext{
${ }^{31}$ Gordon E. Pruett, “A Note on Robert Bellah's Theory of Religious Evolution: The Early Modern Period," Oxford Journal Vol. 34 No. 1 (1973): 54.
}

pengulangan ritual menggunakan simbolsimbol tersebut, melainkan juga penekanan makna dari simbol-simbol tersebut. Bukan hanya makna teologis yang ditekankan, melainkan juga makna ritual Perjamuan Kudus sebagai sebuah komunitas. Makna tersebut direkonfirmasi berulang-ulang baik saat melaksanakan ritual maupun dalam khotbahkhotbah dan pengajaran, sehingga solidaritas mekanik terbentuk. Setelah solidaritas mekanik terbentuk, diharapkan bahwa jemaat tidak lagi menganggap satu sama lain sebagai orang asing, melainkan satu tubuh Kristus, bukan hanya untuk kepentingan organisasi gereja tetapi juga kepentingan komunitas secara menyeluruh.

\section{Isu Kesakralan Gereja: Reklarifikasi Sakral dan Nonsakral}

Sebagaimana yang dikatakan Durkheim, sebuah agama seharusnya memiliki klasifikasi hal-hal sakral dan nonsakral. Klasifikasi ini mempermudah sebuah klan untuk menentukan peraturan-peraturan yang mengikat komunitas tersebut, serta hukuman-hukuman bagi yang melanggarnya. Agama, menurut Durkheim, memiliki fungsi negatif, yaitu sebagai penentu peraturan dan larangan bagi komunitas, dengan tujuan menjaga kesakralan komunitas itu sendiri. ${ }^{32}$

Dalam suku primitif Australia, peraturanperaturan dan larangan-larangan ini dibuat berkaitan dengan ritual yang dilakukan. Contohnya, seseorang yang belum dianggap religius dilarang menyentuh churinga (yang dianggap sakral). Kaum perempuan yang dianggap profan, tidak diizinkan ikut dalam ritual-ritual, hanya melihat saja dari jauh. Ada daging-daging yang dilarang untuk dimakan karena berhubungan dengan totem tertentu. Bagi yang melanggar peraturan-peraturan tersebut, dipercayai orang itu akan menerima hukuman alamiah seperti sakit atau

\footnotetext{
${ }^{32}$ Durkheim, The Elementary Forms of Religious Life,
} 306. 
kematian. Ada pula hukuman positif yang berasal dari komunitas, seperti stigma buruk dari komunitas, dikucilkan sementara, dipersalahkan pihak keluarga, dan lain-lain. Ada pula peraturan dan larangan yang berlaku bagi orang luar klan mereka. Peraturan ini dibuat agar orang luar tidak dapat melanggar hal-hal yang mereka anggap sakral. ${ }^{33}$ Semua peraturan dan larangan yang dibuat memiliki esensi yang sama: Memisahkan yang sakral dengan nonsakral.

Dalam Protestanisme, terdapat pula konsep sakral. Menurut Berkhof, kesakralan gereja adalah salah satu dari tiga atribut gereja selain kesatuan dan universalitas gereja. ${ }^{34}$ Namun di zaman sekarang, terjadi banyak peristiwa yang membuat kesakralan gereja dipertanyakan. Pertama, hal ini terlihat pada pasifnya gereja merespons serangan yang berasal dari luar gereja terhadap gereja. Contohnya di Indonesia ketika seorang ulama menghina ajaran Kristen mengenai Yesus sebagai Anak Allah dengan mengatakan, "Kalau Tuhan beranak, bidannya siapa?"35 Respons umat Protestan terhadap penghinaan itu adalah diam. Sebaliknya, mahasiswa Katoliklah yang melaporkan kejadian itu sebagai pelecehan agama. ${ }^{36}$ Demikian pula pembubaran kebaktian Minggu di Riau oleh masyarakat, dianggap sebagai hal yang kurang serius karena tidak menganggap bahwa hal itu adalah pelanggaran serius, hanya dianggap sebagai intoleransi dan bukan penghinaan terhadap komunitas. Gomar Gultom, ketua PGI saat itu menanggapi kasus ini dengan mengatakan, "Menjalankan ibadah merupakan hak konstitusional warga, sebagai bagian dari kebebasan beribadah yang

\footnotetext{
${ }^{33}$ Pickering, Durkheim's Sociology of Religion: Themes and Theories, 11.

${ }^{34}$ Berkhof, Teologi Sistematika 5: Doktrin Gereja, 39-47.

35"Rizieq Shihab Dilaporkan Ke Polisi, Dituduh Lecehkan Umat Kristen," BBC News, https://www.bbc.com/ indonesia/indonesia-38435195, diakses pada 14 April 2020.

${ }^{36}$ Egi Adyatama, "Rizieq Shihab Dipolisikan Dengan Tudingan Menistakan Agama," Tempo, https://nasional. tempo.co/read/830565/rizieq-shihab-dipolisikan-dengantudingan-menistakan-agama, diakses pada 14 April 2020.
}

dijamin oleh Undang-undang. Ketiadaan izin dan sebagainya tidak semestinya menghalangi orang untuk beribadah." ${ }^{\prime 37}$

Kedua, praktik di dalam gereja sendiri yang tampaknya mengabaikan kesakralan gereja. Terbukanya Protestan terhadap ilmu pengetahuan, termasuk penyelidikan-penyelidikan historis terhadap hal-hal sakral, contohnya Alkitab, membuat yang sakral dan nonsakral tidak lagi terpisah. Metode-metode penafsiran yang baru terhadap Alkitab membuat Alkitab bisa ditafsirkan dalam berbagai sudut pandang sehingga tidak lagi sakral. Pengadaan ibadah di ruko-ruko dan mal-mal oleh beberapa gereja, bukan sebuah tempat khusus yang dianggap sakral (contoh: gedung gereja Katolik), juga ikut mengurangi rasa hormat terhadap kesakralan rumah ibadah. Jemaat menganggap rumah ibadah hanya sekedar tempat yang digunakan untuk kebaktian, dan bukan sesuatu yang disakralkan. Ada rumah ibadah yang menggunakan lampu-lampu seperti di tempat hiburan untuk menambah suasana meriah. Demikian juga liturgi-liturgi di dalam gereja tidak lagi berbeda dengan musik-musik sekuler. Halhal seperti ini terjadi tanpa kesadaran bahwa peniruan-peniruan terhadap yang profan dapat menyebabkan garis tipis antara sakral dan nonsakral semakin menghilang.

Ketiga, banyak hal yang dilakukan umat Protestan tidak terkontrol secara moral oleh gereja. Hal-hal ini terjadi di dalam gedung gereja maupun di luar gedung gereja. Contoh di dalam gereja: banyak jemaat yang datang terlambat ibadah, menggunakan baju yang kurang sopan dalam ibadah, mengganggu ibadah dengan ribut sendiri, bermain gadget saat khotbah disampaikan. Contoh dalam hidup sehari-hari, banyak kasus perceraian, perzinahan, korupsi, dan lain-lain.

37"PGI: Pembubaran Ibadah Di Gereja Indragiri Hilir Melukai Umat," CNN Indonesia, https://www.cnn indonesia.com/nasional/20190827111757-20-424937/pgipembubaran-ibadah-di-gereja-indragiri-hilir-melukaiumat, diakses pada 14 April 2020. 
Hal ini dilakukan oleh jemaat gereja baik tanpa sepengetahuan maupun dalam sepengetahuan pemimpin gereja. Lemahnya kontrol pemimpin gereja terhadap ritual dan kehidupan pribadi jemaat menyebabkan halhal tersebut lolos dari pengamatan.

Sebenarnya bukan hal yang mengagetkan bahwa agama Protestan tidak memiliki batas yang jelas antara yang sakral dan nonsakral. Martin Luther, sebagai Bapak Protestan, menolak adanya dualisme sakral dan nonsakral, yang tampak dalam usahanya menentang pembedaan antara kaum klerus dan kaum awam. Luther mengatakan,

It is pure invention that pope, bishop, priests and monks are to be called the 'spiritual estate' while princes, lords, artisans, and farmers the 'temporal estate.' This is indeed a piece of deceit and hypocrisy. Yet no one need be intimidated by it, and for this reason: all Christians are truly of the 'spiritual estate,' and there is no difference among them except that of office. ${ }^{38}$

Penolakan ini kemudian dilanjutkan oleh John Calvin dengan doktrin anugerah umum. Calvin mempercayai bahwa segala hasil karya orang-orang nonkristen juga harus diterima sebagai anugerah Tuhan (Instit. 2.2.12).

Dari alasan di atas, tampaknya sulit menyatukan konsep sakral dan nonsakral Durkheim dengan konsep Protestan. Protestanisme tidak mungkin kembali pada zaman di mana setiap penghinaan pada Kekristenan harus dihukum dengan keras. Pickering mengatakan bahwa penghinaan terhadap Yesus di zaman sekarang, khususnya di Inggris, tidak akan mendapatkan hukuman yang keras, baik dari gereja maupun dari segi hukum. Ia menyatakan bahwa sistem sosial di barat telah berpindah dari Kristen tradisi-

${ }^{38}$ Martin Luther, Three Treatises, terj. Charles M. Jacobs dan James Atkinson, ed. ke-2 (Minneapolis: Fortress, 1970), 12. onal menjadi humanis. Protestanisme berperan aktif dalam pergeseran ini. ${ }^{39}$

Apa yang dibutuhkan di sini untuk usaha revitalisasi gereja bukanlah merombak ulang konsep Protestan tentang sakral dan nonsakral, melainkan klarifikasi ulang mengenai apa yang digolongkan sebagai sakral dan nonsakral. Ketika Luther, Calvin, Kuyper, dan teolog-teolog Protestan lainnya menolak pemisahan sakral dan sekuler, bukan berarti sama sekali tidak ada yang digolongkan sebagai sakral dalam Protestanisme. Konsep sakral dalam Protestanisme lebih mengacu pada kekudusan hidup jemaat gereja seharihari jemaat, yaitu tercermin dalam bagaimana secara moral, jemaat terpisah dari dosa dan kedurhakaan dunia. Standar kekudusan ini adalah Alkitab dan juga moralitas secara umum. Para peneliti Durkheim meyakini bahwa di zaman sekarang konsep sakral Durkheim dapat diterjemahkan sebagai moralitas secara umum. Eric Gans menyebutnya sebagai "penolakan terhadap dorongandorongan antagonis." ${ }^{40}$ Sedangkan Douglas Marshall menyebutnya sebagai "penilaian moral" (moral judgment), dan menurut Marshall definisi sakral ini juga diterapkan oleh Protestanisme. ${ }^{41}$ Argumen ini didukung oleh Riley, "The Christian law of love thy neighbor' motivated primarily by love of God, to be sure, shows a shift in the directed end of morality from the supernatural to the social. The Protestant revolution in Christianity furthered this attention on the human as a sacred end, diminishing the role of ritual and elaborating the requirements of Christians to their fellows." ${ }^{42}$

${ }^{39}$ W.S.F Pickering, "The Eternality of the Sacred: Durkheim's Error?," Archives des sciences sociales des religions 69 (1990): 97-99.

${ }^{40}$ Eric Gans, "The Sacred and the Social: Defining Durkheim's Anthropological Legacy," Anthropoetics: The Journal of Generative Anthropology 6, no. 1 (2000): 4.

${ }^{41}$ Douglas A Marshall, "Temptation, Tradition, and Taboo: A Theory of Sacralization," Sociological Theory 28, no. 1 (2010): 73.

${ }^{42}$ Riley, The Social Thought of Emile Durkheim, 150. 
Dosa dan perilaku amoral dianggap nonsakral dalam kehidupan jemaat Protestan. Tanpa mengabaikan konsep pengudusan yang berasal dari Allah kepada gereja-Nya, gereja juga harus menyadari kewajibannya untuk hidup terpisah dari dosa dunia. Demi menjaga kesakralan ini, perlu ditata ulang aturan dan larangan pada warga gereja dan juga penerapan disiplin gereja bagi yang melanggarnya, termasuk jika yang melanggar aturan moral ini adalah pemimpin gereja.

\section{Isu Pertumbuhan Gereja: Pembentukan Klan-Klan Baru}

Isu pertambahan denominasi baru dalam gereja menjadi fenomena di Indonesia. Data Dirjen Bimas Kristen menunjukkan bahwa sampai tahun 2013, terdapat 323 organisasi gereja induk (denominasi), ribuan gereja lokal, sekolah, dan yayasan Kristen Protestan di Indonesia. ${ }^{43}$ Jumlah ini belum termasuk ratusan denominasi baru yang ingin mendaftarkan diri ke Kementrian Agama, namun belum disahkan. Pertambahan denominasi ini memiliki kemiripan dengan penelitian Durkheim mengenai pembentukan klanklan baru.

Dalam penelitian Durkheim terhadap suku primitif di Australia, komunitas dalam sebuah suku terbagi menjadi dua phratry, dan tiap phratry terdiri dari banyak klan. Phratry adalah komunitas besar yang beranggotakan orang-orang dari garis keluarga yang sama. Klan adalah kelompok-kelompok yang lebih kecil dari phratry, di mana anggota-anggotanya masih memiliki ikatan darah. Masingmasing klan memiliki totem, dan masingmasing phratry juga memiliki totem. Setiap phratry dan klan-klannya memiliki totem yang melambangkan sesuatu dalam alam semesta, entah itu benda-benda langit, tumbuhan,

\footnotetext{
${ }^{43}$ Nuhrison M. Nuh et al., Pemimpin Gereja Moratorium Organisasi Gereja dan HAM (Jakarta: Puslitbang Kehidupan Keagamaan Badan Litbang dan Diklat Kementerian Agama RI, 2015), 5.
}

hewan, bahkan manusia. Durkheim memberi contoh dalam suku Mount Gambier, terdapat dua phratry, Kumite dan Kroki. Kumite memiliki totem burung kakatua berwarna hitam, sedangkan Kroki memiliki totem burung kakatua putih. Totem-totem yang dimiliki phratry ini juga mempengaruhi totem-totem yang dimiliki oleh klan-klannya. ${ }^{44}$

Klan-klan dalam sebuah suku ini memiliki kemungkinan untuk memecah. Pemecahan ini disebabkan oleh sesuatu yang alamiah, tidak harus karena perselisihan, bisa karena bertambahnya populasi, pertemuan dengan kebudayaan baru, dan pembentukan kelompokkelompok kecil dalam klan karena kedekatan individu. Klan-klan yang memecah ini disebut sebagai subklan. Ketika sebuah klan memecah menjadi subklan, maka mereka akan membentuk totem-totem baru, yang disebut sebagai subtotem. ${ }^{45}$ Subtotem ini dalam urutan hierarkis lebih rendah dari totem. Dalam berjalannya waktu, subtotem bisa berubah menjadi totem, yaitu saat klan baru telah terpisah sepenuhnya dari klan yang lama dan dapat mendefinisikan dirinya sendiri sebagai berbeda dengan klan sebelumnya. Sebelum subklan menjadi sebuah klan baru maka mereka memiliki dua totem, yaitu totem utama yang sama dengan klannya dan subtotem, yang memiliki klasifikasi yang mirip dengan totem utama. Contohnya dalam suku Arunta, awalnya terdapat 60 totem namun berkembang menjadi 420 totem termasuk subtotem.

Pemecahan klan ini, menurut Durkheim tidak harus dipandang sebagai sebuah perpecahan dalam totemisme, melainkan menambah jenisjenis totem yang melambangkan alam semesta. Justru semakin banyak klan memecah dan membentuk totem baru, maka definisi atas alam semesta dalam suku tersebut akan semakin beragam. Keragaman tersebut akan

\footnotetext{
${ }^{44}$ Durkheim, The Elementary Forms of Religious Life, 147.

${ }^{45}$ Ibid., 152.
} 
memperkaya sebuah suku secara keseluruhan sehingga pada akhirnya diharapkan sebuah suku memiliki definisi yang lengkap mengenai kosmologi. ${ }^{46}$

Pemikiran Durkheim mengenai memecahnya klan dan terbentuknya totem baru ini, menurut John Constantine Hanges, dapat diaplikasikan dalam sejarah terbentuknya gereja, khususnya saat Kekristenan memecah dari Yudaisme. ${ }^{47}$ Totem-totem pun mengalami perubahan, di mana dalam Kekristenan mempercayai Allah Tritunggal sedangkan Yudaisme masih mempercayai YHWH sebagai Allah yang Esa. Lambang-lambang yang dianggap sakral juga sudah mengalami perubahan, Kekristenan mempercayai salib, Alkitab, roti dan anggur Perjamuan Kudus sebagai lambang-lambang sakral, sedangkan Yudaisme masih mempercayai pengorbanan binatang, Kitab-kitab Yahudi dan Talmud, darah domba, roti tak beragi, dan lain-lain. Ini sebanding dengan apa yang dikatakan Durkheim, bahwa klan-klan memecah dan membentuk totem baru untuk membedakan dirinya dengan klan induknya.

Selanjutnya, Kekristenan pun memecah menjadi berbagai aliran dan denominasi. Meskipun tidak membentuk sebuah agama baru, dapat dikatakan Kekristenan mengalami pemecahan klan. Sebagaimana yang dijelaskan Durkheim, pemecahan ini bukanlah sesuatu yang buruk, melainkan sesuatu yang baik. Bahkan Durkheim meyakini pemecahan ini adalah ciri agama modern, mencegah agama tersebut dari kepunahannya. Dalam setiap pemecahan ini, pasti terdapat hal-hal yang baru dalam mendefinisikan alam semesta, dan itu menyebabkan pemahaman akan semesta dalam pemikiran Kristen semakin utuh.

\footnotetext{
${ }^{46}$ Ibid., 157.

${ }^{47}$ James Constantine Hanges, "Durkheim and Early Christianity," dalam Reappraising Durkheim for the Study and Teaching of Religion Today, ed. Thomas A. Idinopulos dan Brian C. Wilson (Leiden: Brill, 2002), 145.
}

Berkaca pada pemikiran Durkheim, seharusnya pemecahan dalam Kekristenan dapat dilihat secara positif. Pemecahan denominasi dapat direfleksikan sebagai makin bertumbuhnya agama Kristen, dan bertambahnya tradisitradisi Kekristenan sehingga gereja-gereja di Indonesia semakin diperkaya. Masing-masing gereja, dengan keunikannya tersendiri dapat menjadi daya tarik tersendiri bagi jemaat, dan dengan demikian dapat menjangkau berbagai lapisan masyarakat dengan preferensi yang berbeda. Bertambahnya denominasi gereja di Indonesia tidak harus selalu dipandang sebagai persaingan dan perselisihan dengan denominasi sebelumnya, mengingat adanya denominasi baru yang masih berhubungan baik dengan denominasi yang lama. Pertambahan denominasi, pluralisasi pengajaran dan doktrin, beragam model liturgi dan ritual, harus diterima dengan tangan terbuka. Bahkan pemecahan ekstrim, seperti pembentukan gereja online pun harus didukung sebagai bentuk klan baru dalam Kekristenan.

Namun bukan berarti tidak ada pemecahan gereja yang bersifat negatif atau ekses. Kebebasan yang tidak terkontrol dalam memecah menjadi denominasi baru dapat dicemari oleh egoisme dan kultus individu (cult of individual). Alasan-alasan pecahnya sebuah denominasi tidak pernah diketahui secara pasti kecuali oleh pemimpin dan komunitas itu sendiri. Bisa saja sebuah denominasi memberi alasan yang kelihatannya baik, seperti memecah demi mendewasakan umat, dan lain-lain, namun sejatinya adalah hanya ingin memperkuat kekuasaan pribadi. Demikian pula ada yang menganggap denominasi-denominasi lain sebagai kompetitor: kompetitor dalam hal luasnya gereja, banyaknya aset, banyaknya jemaat, dan lain-lain.

Motif-motif buruk dari pemecahan denominasi akan tampak ketika pemecahan itu tidak mencapai tujuannya yang utama, yaitu mendefinisikan identitas komunitas dan membedakannya dari komunitas yang lama. 
Kenyataannya ada gereja-gereja yang memecah namun dari segi liturgi, doktrin, maupun pengajarannya tidak ada yang berbeda sama sekali dengan denominasi yang lama, yang berbeda hanyalah pemimpinnya. Pemecahan semacam ini bukannya membentuk identitas yang baru dari sebuah komunitas, melainkan memperkuat kekuasaan dari satu pihak. Ada gereja-gereja yang memecah karena dengan memecah maka uang dan aset yang terkumpul tidak lagi harus disetorkan kepada denominasi awal. Ada pula yang memecah karena pemimpin ingin menguasai dan memiliki otoritas penuh atas jemaat yang dimiliki. Dengan demikian, uang, popularitas, dan kekuasaan menjadi subtotem dan totem baru mereka, yang bukan didasarkan pada kepentingan komunitas. Hal ini menyebabkan totem baru yang dibentuk hanyalah merupakan totem palsu (pseudo-totem). Totem palsu sama sekali tidak memperbaharui identitas komunal, melainkan hanya bentuk dari egoisme dan keinginan belaka untuk terpisah dari komunitas yang lama.

Namun demikian, pemecahan gereja menjadi denominasi-denominasi tidak harus dihentikan hanya karena adanya ekses-ekses dalam praktiknya. Pemecahan itu tidak akan dapat dicegah oleh siapapun karena merupakan sesuatu yang alamiah, bahkan menandakan bahwa agama tersebut terus berevolusi dan tidak mati. Namun setiap klan baru perlu mendefinisikan keberbedaannya dengan klan yang lama, membentuk subtotemnya sendiri, sehingga tujuan utama pemecahan, yaitu bertambahnya wawasan dunia dalam sebuah agama, tetap dapat terpenuhi. Untuk mencapai hal itu juga diperlukan pemikiran yang terbuka dari orangorang Kristen sendiri, bahwa sebuah agama harus terus berkembang, agar tidak punah di masa depan. Jika sebuah perkembangan selalu dihentikan secara prematur dan cepat dilabeli sebagai "sesat," maka wawasan dunia Kristen tidak akan dapat menjawab isuisu yang muncul dalam modernisasi, dan seperti kata Durkheim, "akan ditelan oleh perkembangan ilmu pengetahuan." 48

\section{KESIMPULAN: PROTESTANISME ADALAH REVITALISASI TERUS- MENERUS}

Hidup pada abad 18, Durkheim telah membangun sebuah pemikiran tentang agama modern di masa depan (future religion). Berangkat dari penelitiannya mengenai agama kuno suku primitif Australia, Durkheim "menubuatkan" bahwa agama modern di masa depan akan jauh meninggalkan prinsip-prinsip agama kuno, karena menurutnya agamaagama kuno telah punah karena ditelan oleh perkembangan ilmu pengetahuan. Durkheim memberikan ciri-ciri agama modern di masa depan sebagai agama yang memiliki kebebasan berpikir, memberikan hak setiap jemaat untuk mengkritik agama mereka sendiri, dan inisiatif individu yang lebih tinggi. Hal-hal ini dimiliki agama modern, bahkan lebih dari Protenstantisme liberal yang Durkheim hadapi di zamannya. Selain itu, agama modern, seperti agama kuno, tetap akan menekankan dimensi sosial, seperti persatuan komunitas, pertemuan-pertemuan ibadah secara berkala, pengetahuan obyektif tentang yang sakral dan nonsakral, dan keadilan sebagai salah satu tema sentral doktrinnya.

Semua karakteristik ini, menurut Pickering, memiliki kemiripan dengan Protestanisme. ${ }^{49}$ Pernyataan ini dapat disetujui, melihat karakteristik agama modern yang diungkapkan Durkheim memiliki kesamaan dengan Protestanisme zaman sekarang. Dalam Reforming Protestantism, Douglas Ottati mengatakan, "We ourselves, all of the peoples, nations, and churches will be subject to criticism, and all will be called to repentance." ${ }^{50}$ Demikian juga

${ }^{48}$ Durkheim, The Elementary Forms of Religious Life, 467.

${ }^{49}$ Pickering, Durkheim's Sociology of Religion: Themes and Theories, 479.

${ }^{50}$ Douglas F Ottati, Reforming Protestantism: Christian Commitment in Today's World (Louisville: Westminster John Knox, 1995), 42. 
tema sentral dari Protestanisme zaman sekarang sudah mulai mencakup pula persoalanpersoalan keadilan. Protestanisme mendukung jemaatnya untuk bergabung dalam bidang sosial-politik dan ekonomi. John M. Perkins berkata,

I wish churches spent more time thinking about how their members could love one another and share a common life by working together as a community. Part of the reason our churches are so individualistic is that we just accept the economic system of our culture without question ... If we take our communities seriously as economic places, we'll spend more time thinking about creating good work than we spend thinking about more relevant worship styles or bigger church buildings. ${ }^{51}$

Demikian juga Protestanisme bergerak untuk menjaga lingkungan. Andrew R.H. Thompson mengatakan, "It is clear that responding to climate change and ecological crises is an urgent problem for the church." 52

Optimisme Durkheim bahwa agama modern tidak akan punah dan tidak akan ditelan oleh ilmu pengetahuan patut diapresiasi dalam Protestanisme. Namun syaratnya, gereja Protestan harus terus menerus melakukan revitalisasi agar tetap bertahan untuk menghadapi perkembangan teknologi dan ilmu pengetahuan. Revitalisasi yang telah dibahas di makalah ini adalah rekonfirmasi simbolsimbol, reklarifikasi sakral dan nonsakral, dan reformasi lewat multiplikasi klan terusmenerus, merupakan sebagian saja dari revitalisasi yang harus terus-menerus dilakukan gereja Protestan. Agar tetap bertahan di era apapun, "Semper Reformanda," Protes-

\footnotetext{
${ }^{51}$ Charles Marsh and John Perkins, Welcoming Justice: God's Movement Toward Beloved Community (Downers Grove: InterVarsity, 2018), 123.

${ }^{52}$ Andrew R.H Thompson, "Eco-Solidarity: Ecclesiology En Conjunto in the Anthropocene Epoch," Anglican Theological Review 101, no. 4 (2019): 696.
}

tanisme harus terus-menerus menemukan bentuk-bentuk yang baru.

\section{DAFTAR KEPUSTAKAAN}

Bellah, Robert N. "Durkheim and Ritual." Dalam The Cambridge Companion to Durkheim, diedit oleh Jeffrey C. Alexander dan Philip Smith, 183-210. Cambridge: Cambridge University Press, 2005.

Berkhof, Louis. Teologi Sistematika 5: Doktrin Gereja. Surabaya: Momentum, 2003.

Durkheim, Émile. Suicide: A Study in Sociology. Diterjemahkan oleh John A. Spaulding dan George Simpson. London: Routledge Classics, 2002.

- The Division of Labor in Society. Diedit oleh Lewis A. Coser. Diterjemahkan oleh W.D. Halls. London: Macmillan, 1984.

- The Elementary Forms of Religious Life. Diterjemahkan Karen E. Fields. New York: Free Press, 1995.

Gans, Eric. "The Sacred and the Social: Defining Durkheim's Anthropological Legacy." Anthropoetics: The Journal of Generative Anthropology 6, no. 1 (2000): 1-7.

Gustavo, Luiz, and Cunha de Souza. "Division of Labour in Durkheim, Marx, and Honneth: Contributions to a Political Economy of Recognition." Civitas: Journal of Social Sciences 18, no. 3 (2018): 654-668, https://doi.org/10.15448/1984-7289. 2018.3.31068.

Hanges, James Constantine. "Durkheim and Early Christianity." Dalam Reappraising Durkheim for the Study and Teaching of Religion Today, diedit oleh Thomas A. Idinopulos and Brian C. Wilson, 143-162. Leiden: Brill, 2002.

Idinopulos, Thomas. "Preface." Dalam Reappraising Durkheim for the Study and Teaching of Religion Today, diedit oleh Thomas A. Idinopulos and Brian C. Wilson, ix-xix. Leiden: Brill, 2002.

Janssen, Jacques, dan Theo Verheggen. "The Double Center of Gravity in Durkheim's Symbol Theory: Bringing the Symbolism 
of the Body Back In.” Sociological Theory 15, no. 3 (1997): 294-306. https://doi.org/ 10.1111/0735-2751.00036.

Luther, Martin. Three Treatises. Diterjemahkan oleh Charles M. Jacobs dan James Atkinson. Ed. ke-2. Minneapolis: Fortress, 1970.

Marsh, Charles, and John Perkins. Welcoming Justice: God's Movement Toward Beloved Community. Downers Grove: InterVarsity, 2018.

Marshall, Douglas A. "Temptation, Tradition, and Taboo: A Theory of Sacralization." Sociological Theory 28, no. 1 (2010): 64-90.

Nielsen, Donald A. "Auguste Sabatier and the Durkheiminians on The Scientific Study of Religion." Sociological Analysis 47 (1987): 283-301.

Ottati, Douglas F. Reforming Protestantism: Christian Commitment in Today's World. Louisville: Westminster John Knox, 1995.

Pickering, W.S.F. Durkheim's Sociology of Religion: Themes and Theories. Cambridge: James Clark, 2009.

- "The Eternality of the Sacred: Durkheim's Error?" Archives des sciences sociales des religions 69 (1990): 91-108.
Pruett, Gordon E. "A Note on Robert Bellah's Theory of Religious Evolution: The Early Modern Period." Oxford Journal Vol. 34 No. 1 (1973): 50-55.

Riley, Alexander. The Social Thought of Émile Durkheim. California: SAGE, 2015.

Scimecca, Joseph. Christianity and Sociological Theory: Reclaiming the Promise. London: Routledge, 2018.

Sitorus, Fitzerald Kennedy. "Theonomous, Autonomous, and Heteronomous Conscience: Conscience in Luther and Kant, and Indonesian Moral Perception." Dalam Sola Scriptura in Asia, diedit oleh Yongbom Lee and Andrew R. Talbert, 89-107. Oregon: Wipf and Stock, 2018.

Sugiyarto, Wakhid, Suhanah, Reslawati, Nuhrison M. Nuh, Syaiful Arif, Asnawati, dan Sony Dandel. Pemimpin Gereja Moratorium Organisasi Gereja Dan HAM. Jakarta: Puslitbang Kehidupan Keagamaan Badan Litbang dan Diklat Kementerian Agama RI, 2015.

Thompson, Andrew R.H. "Eco-Solidarity: Ecclesiology En Conjunto in the Anthropocene Epoch." Anglican Theological Review 101, no. 4 (2019): 685-696. 